\title{
Effects of the electromagnetic field of Wi-Fi systems and experimental gadget M4 on growth, development and photosynthesis of wheat
}

\author{
J. Roche ${ }^{1}$, N.P. Didyk ${ }^{2 *}$, (1) B.O. Ivanytska ${ }^{2}$, (1) N.V. Zaimenko ${ }^{2}$, O.O. Chudovska ${ }^{2}$ \\ 1 SAS "IRDT", rue Simon Perrot 8, 28700 Denonville, France \\ 2 M.M. Gryshko National Botanical Garden, National Academy of Sciences of Ukraine, Timiryazyevska str. 1, 01014 Kyiv, Ukraine; \\ * nataliya_didyk@ukr.net
}

Received: 05.02 .2020 | Accepted: 16.03 .2020 | Published: 30.06 .2020

\begin{abstract}
The objective of this study was to assess the effects of the electromagnetic field of a Wi-Fi system and the experimental gadget M4 developed by SAS "IRDT" (France) on wheat seed germination, growth and photosynthetic activity of juvenile plants.

Material and methods. The test-plants were grown under controlled conditions of light, temperature and humidity for eight days in a pot experiment modeling the following treatments: (1) without the electromagnetic field of Wi-Fi systems (control); (2) at a distance of $30 \mathrm{~cm}$ from the operating Wi-Fi router; (3) at a distance of $30 \mathrm{~cm}$ from operating Wi-Fi router and the experimental gadget M4.

The test plant development and vitality were assessed using indices of seed germination, growth rates (shoot height, root length, number of lateral roots, shoot and root dry weights), photosynthetic pigment content in leaves, and the number of chloroplasts per a mesophyll cell in foliar tissues.
\end{abstract}

Results. It was found that the electromagnetic field of the Wi-Fi router initially stimulated, but then suppressed the germination of seeds, reduced the growth of shoots and roots, the content of photosynthetic pigments and genesis of the chloroplasts in the mesophyll tissues in leaves of juvenile wheat plants.

The root length was the most sensitive morphometric parameter to the electromagnetic field of the $\mathrm{Wi}-\mathrm{Fi}$ router. The use of the gadget M4 completely compensated the negative impact of the Wi-Fi router on the seed germination, shoots growth, and partially compensated for the suppression of root growth, the genesis of the chloroplasts, chlorophyll $a$ and $b$ content in wheat leaves.

Conclusion. The attenuation effect of gadget M4 against the damaging effect of electromagnetic fields of anthropogenic origin is promising, and further investigations are required to observe the effects in the long term, from sowing to maturity, including the next generation of seeds.

Keywords: Triticum aestivum, radio-frequency electromagnetic fields, Wi-Fi router, gadget M4, plant growth, plant development, photosynthetic pigments, chloroplastogenesis

\section{Introduction}

During the evolution processes, the biosphere has been influenced by electromagnetic fields caused by natural sources. The industrialization has added a number of factors amplifying the existing natural electromagnetic radiation. Presently electromagnetic fields of anthropogenic origin significantly exceed the natural background and have so far become a dangerous environmental factor (Zadoya, 2014).

The World Health Organization (WHO) identified electromagnetic fields as a biologically active factor affecting living 
organisms at the stage of formation and development. In 1995 WHO has introduced the official term "global electromagnetic pollution" and included the problem of electromagnetic pollution in the list of priority problems of humanity, as the degree of pollution increases 10-15 times every decade (Zadoya, 2014; Moroz \& Chemerys, 2017). Today, anthropogenic electromagnetic pollution of the Earth exceeds the natural level 200,000-fold. The results of the assessment of the present-day electromagnetic pollution of an industrial city showed that the former corresponds to the level of the electromagnetic storm (Moroz \& Chemerys, 2017; Kostoff et al., 2020). An essential role in the general anthropogenic electromagnetic pollution of the indoor environment is played by household devices that are widely used by man.

$\mathrm{Wi}-\mathrm{Fi}$ electromagnetic radiation at 3-5 $\mathrm{GHz}$ is in widespread use worldwide. The use of Wi-Fi technology has become increasingly common in many places throughout the community, including schools, parks, restaurants, shopping, and entertainment complexes. Through the use of this technology, electronic devices are connected to a computer network wirelessly using radiofrequency electromagnetic fields (RF-EMF). Wi-Fi is a type of wireless local area network which operates in unlicensed regions of the RF spectrum in the 2.45 and $5 \mathrm{GHz}$ bands. The technology was designed to be used up to a few tens of meters between a device and an access point. Over these short distances, Wi-Fi devices only use low output power, typically limited to $2 \mathrm{~W}$ or less.

Presently research focus on the influence of industrial sources of electromagnetic radiation, but the sources of such radiation in the environment are given insufficient attention. The pervasive use of wireless communication devices in each aspect of everyday life increases the need for assessing the effect of RF-EMF of household appliances on living organisms (Kostoff et al., 2020).

Until now, there is no clear assessment of the impact of Wi-Fi on biological systems. On the one hand, it is known that the wavelength of the Wi-Fi signal corresponds to the relic cosmic microwave background radiation. However, the energy density of the relic cosmic radiation of $0.25 \mathrm{eV} / \mathrm{cm}^{3}$ is much lower than the corresponding value near the Wi-Fi router $\left(100 \mathrm{~mW} / \mathrm{cm}^{2}\right.$, equal to $36 \cdot 10^{9} \mathrm{eV} / \mathrm{cm}^{3}$ - see Castellina et al. (2012)). Therefore the latter can be harmful to living organisms.

The mechanisms of the biological effects of RF-EMF are not elucidated yet. Several hypotheses explain the influence of RF-EMF on biological systems. They are mainly reduced to the induction of currents in the tissues and the direct effect of the field on the membrane structures. It is believed that the exposure to RF-EMF modifies the rate of diffusion through biological membranes, the orientation, and conformation of macromolecules, and the state of the electronic structure of free radicals, $\mathrm{pH}$, electrical conductivity, and redox potential of solutions (Vasileva et al., 2008; Vian et al., 2016). It was also reported that electromagnetic radiation could induce oxidative injury through increasing nitric oxide levels and inhibiting antioxidant defense mechanisms (Atasoy et al., 2013), as well as increased chromosomal aberrations (Kumar et al., 2020). RF-EMF was shown to be more bioactive in causing DNA damage in Drosophila melanogaster as compared with the other types of human-made EMFs (Panagopoulos, 2019). The mechanisms of biological activity of the RF-EMF are mainly nonspecific and are associated with the changes in the functioning of the organism's regulatory systems (Vian et al., 2016).

While the vast majority of studies have focused on animals and humans because of health concerns, higher plants have been provided with much less attention. However, plants constitute an outstanding model to study biological effects of EMFs: due to immobility, they keep a constant orientation in the EMFs, and a high ratio of surface area to volume optimizes their interaction with the environmental factors (Vian et al., 2016). Published results prove that EMF of even small amplitudes evokes multiple responses in plants. Notably, it was shown that at the distance of $5 \mathrm{~cm}$ from the Wi-Fi router, its EMF inhibited the germination of seeds and the growth of seedlings of watercress (Lepidium sativum L.) (Blinova et al., 2015). In other studies, it was shown that RF-EMF (900$1800 \mathrm{MHz}$ ) inhibited the growth of seedlings of soybeans (Halgamuge et al., 2015), and five bean species (Chen \& Chen, 2014). A connection between unusual (generally unilateral) tree damage and exposure to RF-EMF from mobile 
phone masts was shown by long-term (20062015) field monitoring study performed in the cities of Bamberg and Hallstadt in Germany (Waldmann-Selsam et al., 2016).

Despite the growing attention of plant physiologists to the effects of RF-EMF on plant growth and development, there is still no unequivocal assessment of the effect of this factor on plant organisms. Assumptions about the possible mechanisms of these effects are also unclear and contradictory.

The objective of our studies was to evaluate the effect of RF-EMF of the Wi-Fi systems and an experimental gadget M4 (developed by SAS "IRDT", France) on seed germination, growth and photosynthetic activity of juvenile plants of wheat.

\section{Material and methods}

As a test-plant, we used seeds of Triticum aestivum L. 'Smuglianka', which is characterized by uniform quick germination and seedling growth. Our preliminary test showed high sensitivity of this cultivar to RF-EMF. The good potential of indices of the growth rate of wheat seedlings for phytoindication of harmful impacts of EMF was also demonstrated by other authors (Afzal \& Mansoor, 2012; Moroz \& Chemerys, 2017). As a source of Wi-Fi radiation, we used router TP-Link AC1200 (TP-Link Technologies Co., LTD, PRC). The device emits radio waves in two frequency bands -2.4 and $5 \mathrm{GHz}$, which were applied simultaneously.

Two series of experiments were conducted at the same time. The first one was without Wi-Fi radiation (shielded from the possible remote RF-EMF sources in the basement room of the laboratory at the allelopathy department of the M.M. Gryshko National Botanical Garden). The second one was in the presence of remote (10-15 m away from the experimental site) Wi-Fi radiation (laboratory building of the department of chemosystematics and bioindication of the M.M. Gryshko National Botanical Garden).

Seeds of the test plants were surface sterilized with $1 \%$ sodium hypochlorite and sown ( 8 seeds per a pot) into the $200 \mathrm{ml}$ plastic pots filled with sterilized (at a temperature of $100^{\circ} \mathrm{C}$ ) and $2-\mathrm{mm}$ sieved sand. The test-plants were grown under controlled conditions of light intensity of 3500 lux, the temperature of $26-28^{\circ} \mathrm{C}$, and soil moisture of $50-60 \%$. Each of two mentioned series included three experiments, lasting eight days, in which they simulated the following: (1) the absence of electromagnetic RF-EMF of Wi-Fi router; (2) within $30 \mathrm{~cm}$ of an operating Wi-Fi router; (3) within $30 \mathrm{~cm}$ of an operating Wi-Fi router and an experimental gadget M4. The gadget was located between the Wi-Fi router and test-plants.

The dynamics of the test-plants development and their vitality were assessed using the following indices: seed germination (number of seeds germinated on 2, 3, 4, 5, 6, 7, and 8 days after sowing). The shoot height was measured daily after the emergence of seedlings and until the end of the experiment. At the end of the experiment, on the eighth day after sowing, the morphometric parameters of growth (shoot height, root length number of lateral roots, dry weight of shoots and roots) were evaluated. Also, the content of photosynthetic pigments in leaves and the number of chloroplasts per a mesophyll cell in juvenile plants were determined. The photosynthetic pigments (chlorophylls $a$ and $b$, and carotenoids) were extracted from freshly collected leaves with dimethylsulfoxide. The quantitative content was determined spectrophotometrically by the method of Hiscox et al. (1979), spectrophotometer Specord 200 (Analytik Jena, 2003). Counting of the number of chloroplasts per mesophyll cell was conducted using the technique described in Mokronosov (1978). Fresh leaves were macerated with $5 \mathrm{M} \mathrm{HCl}$ and colored with "Astra Blau" (Merck) colorant. The measurements of the chloroplast counts were conducted using software of light illuminated microscope Zeiss with installed photo camera Canon at $\times 400$ magnification.

Statistical analysis and visualization of the results of the studies were performed using analysis of variance with the help of StatSoft Statistica 10.0 software and MS Excel 2007.

\section{Results and discussion}

All tested EMFs (including EMF of Wi-Fi router with gadget M4) significantly influenced seed germination, shoot and root growth, the genesis of the chloroplasts and biosynthesis of photosynthetic pigments (chlorophylls $a, b$, and carotenoids) in the leaves of wheat 

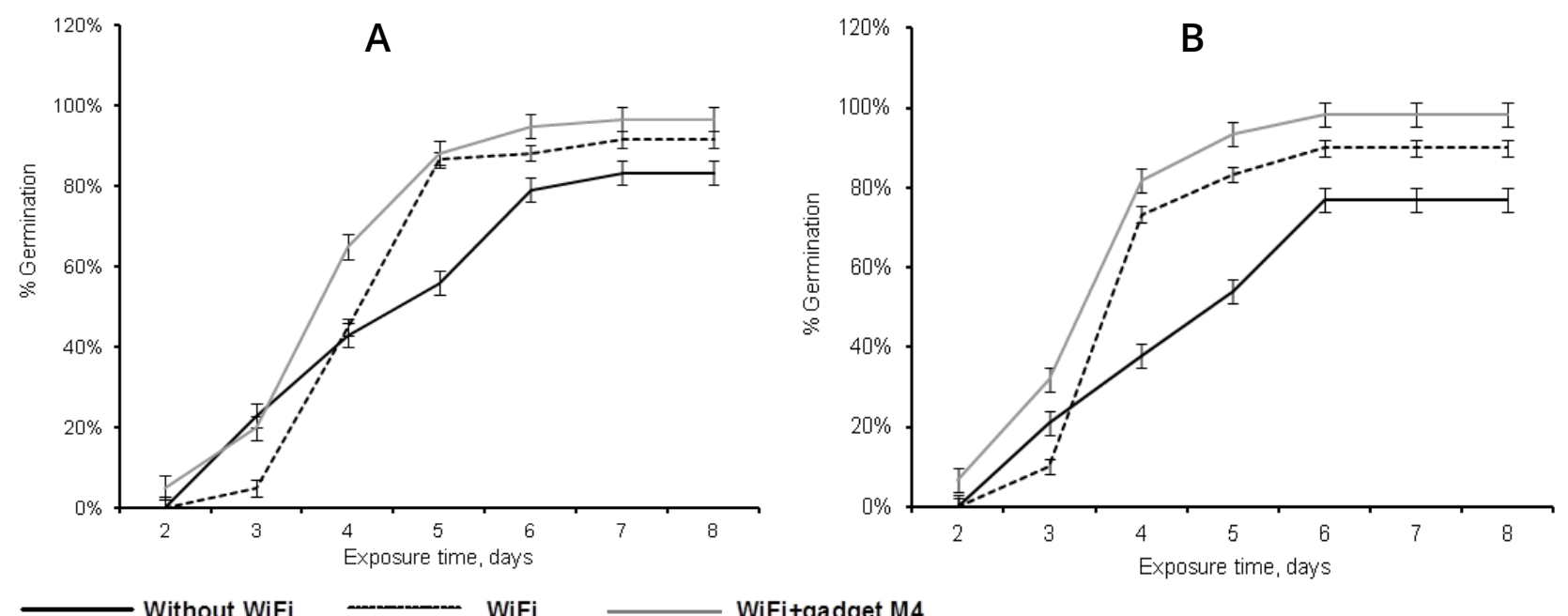

Figure 1. The effects of EMFs of Wi-Fi router and gadget M4 on the wheat seed germination rate (weighted averages): A - without remote Wi-Fi, B - remote Wi-Fi present. Vertical bars - the least significant difference (LSD).
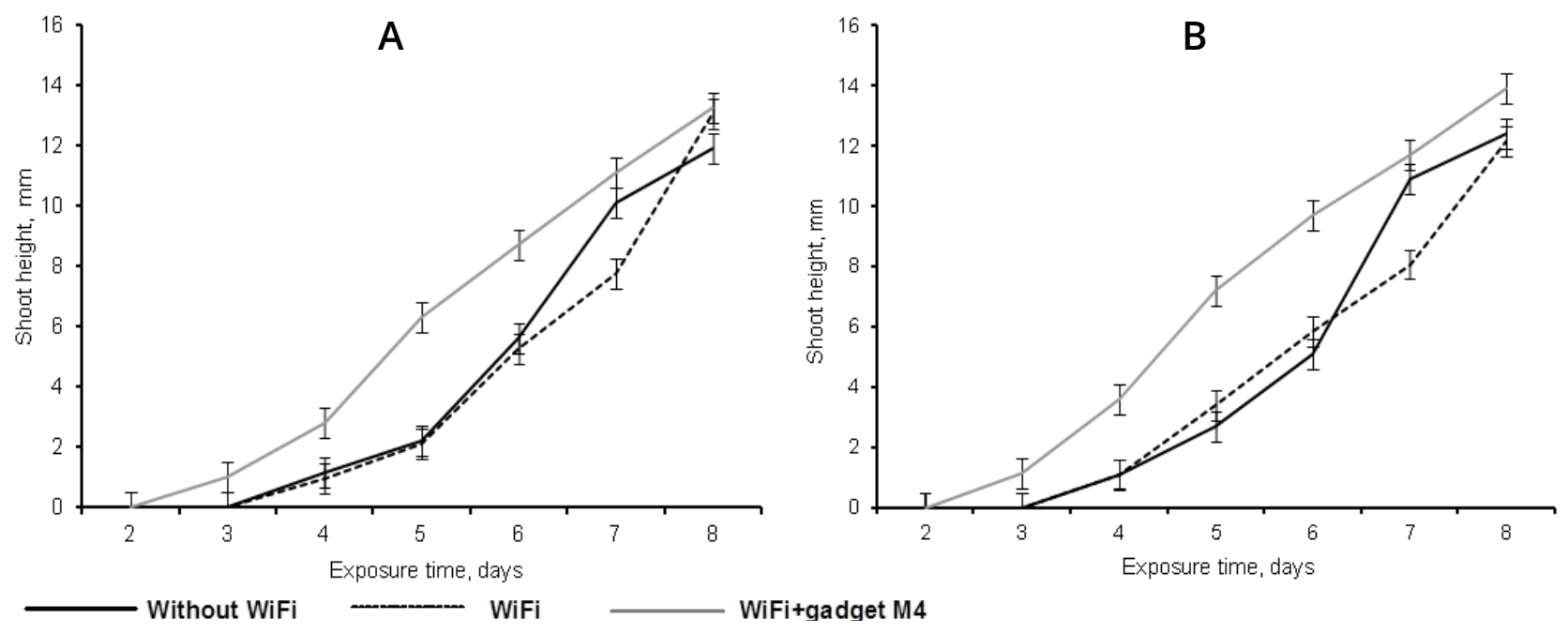

Figure 2. The effects of EMFs of Wi-Fi router and gadget M4 on shoot elongation of wheat seedlings (weighted averages): A - without remote Wi-Fi, B - remote Wi-Fi present. Vertical bars - the least significant difference (LSD).

seedlings. However, the results of two series of experiments revealed the lack of a strong effect of additional remote Wi-Fi on the tested plants.

During the first days of seeds development, EMF of the Wi-Fi router somewhat accelerated the germination (Fig. 1). However, at the end of the experiment, the seeds exposed to EMF of the Wi-Fi router had a $27 \%$ lower germination index compared to control (at the absence of $\mathrm{Wi}-\mathrm{Fi}$ router and gadget M4). The application of the gadget M4 not only compensated the negative impact of the EMF of the Wi-Fi router on the germination of wheat seeds but also stimulated the germination rate by $7 \%$ as compared to the control.
Many studies report modifications of plant growth and development after exposure to high-frequency electromagnetic field (HF-EMF) (Vian et al. 2016). Seed exposure to HF-EMFs generally results in a reduced germination rate (Blinova et al., 2015; Vian et al., 2016), while in other cases germination is unaffected (Sharma \& Parihar, 2014) or even stimulated (Jinapang et al., 2010; Mildažienè et al., 2019). The results of our studies confirmed the sensitivity of wheat seeds to HF-EMF and the suitability of this test-plant for phytoindication of EMF.

The EMF of the Wi-Fi router inhibited the growth of wheat coleoptiles at the beginning of observations. However, from the sixth day 

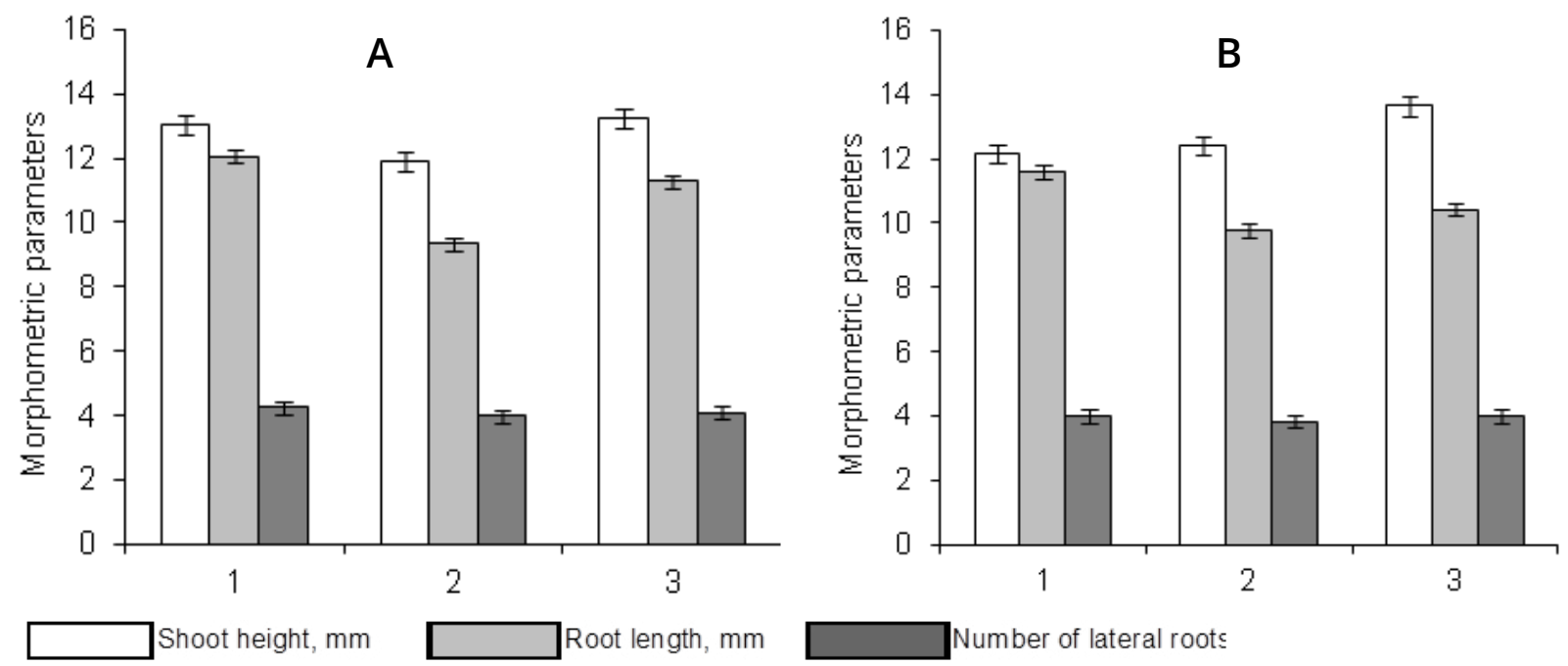

Figure 3. The effects of EMF of Wi-Fi router and gadget M4 on the shoot height, root length, and the number of lateral roots in juvenile wheat plants (weighted averages): A - without remote Wi-Fi, B - remote Wi-Fi present. 1 - without Wi-Fi router, 2 - Wi-Fi router, 3 - Wi-Fi router + gadget M4. Vertical bars - LSD.

until the end of the observations, the effect of the EMF of the Wi-Fi router on the shoot elongation was stimulative (Fig. 2).

In the presence of the gadget M4 the shoot elongation in wheat seedlings was stimulated as compared to control throughout the observation period. At the initial stage of the wheat seedlings development (this stage is most sensitive to the effects of environmental stressors), the biological effects of gadget M4 were the greatest and reached up to $220 \%$ stimulation as compared to the treatment with Wi-Fi router only. At the end of the experiment, the stimulative effect of M4 gadget was by 11-22\% (compared to the "Wi-Fi router only" treatment) and $30 \%$ compared to the control.

Out of the tested morphometric traits, the root length was the most affected by EMFs. EMF of the Wi-Fi router inhibited the root growth by $20 \%$ and the lateral root formation by $5 \%$ (Fig. 3). While EMF of the gadget M4 stimulated the shoot elongation by $8 \%$ compared to the control and by $11 \%$ compared to the "Wi-Fi router only" treatment and also partially compensated the harmful effects of EMF of the Wi-Fi router on the root growth.

The EMF of the Wi-Fi router suppressed biomass accumulation by shoots and roots of juvenile wheat plants by $9 \%$ and $34 \%$, respectively (Fig. 4). In the presence of M4 gadget, the inhibiting effect of the EMF of the Wi-Fi router was almost wholly compensated.

The inhibiting effect of HF-EMF on the growth of higher plants was shown in several studies. Singh et al. (2012) showed that rhizogenesis (root number and length) was severely affected in mung bean after exposure to cell phone radiation, possibly through the activation of several stress-related enzymes (peroxidases and polyphenol oxidases). Akbal et al. (2012) showed that root growth was reduced by almost $60 \%$ in Lens culinaris Medik. seeds exposed in the dormant state to $1800 \mathrm{MHz}$ EMF radiation. Concomitantly, these authors reported an increase in ROS-related enzymes, lipid peroxidation, and proline accumulation, with all of these responses being characteristics of plant responses to stressful conditions. Kumar et al. (2020) demonstrated inhibition of root length in onion (Allium cepa L.) after $4 \mathrm{~h}$ exposure to 900 and $1800 \mathrm{MHz}$. The authors accentuated clastogenic effects and increased mitotic index and chromosomal aberrations of the tested EMFs.

The inhibiting effect of HF-EMF of Wi-Fi systems on Lepidium sativum seedlings growth was shown by Blinova et al. (2015). In the study conducted by Tkalec et al. (2005) the growth of duckweed (Lemna minor L.) exposed for $14 \mathrm{~h}$ to the electromagnetic field of 400 and $1900 \mathrm{MHz}$ significantly decreased in comparison with the control. Inhibition of the growth of epicotyl and hypocotyl of soybean seedlings exposed in a transverse electromagnetic field of mobile phone pulsed radiation or continuous wave radiation at $900 \mathrm{MHz}$ with $41 \mathrm{~V} \cdot \mathrm{m}^{-1}$ amplitude was shown by Halgamuge et al. (2015). Such inhibition significantly depend on the strength and amplitude modulation of the applied electromagnetic field (Tkalec et al., 2005; 

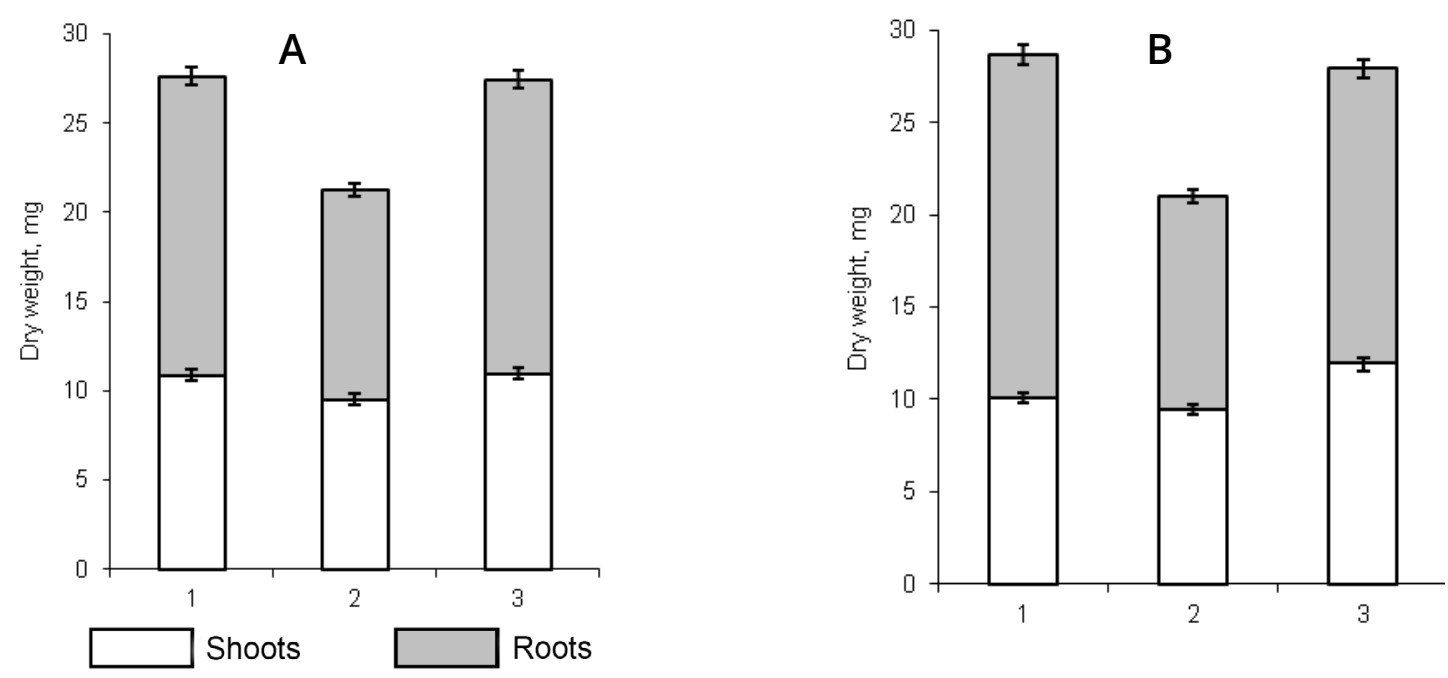

Figure 4. The effects of EMFs of Wi-Fi router and gadget M4 on the dry weights of shoots and roots of juvenile wheat plants: A - without remote Wi-Fi, B - remote Wi-Fi present. 1 - without Wi-Fi router, 2 - Wi-Fi router, 3 - Wi-Fi router + gadget M4. Vertical bars - LSD.
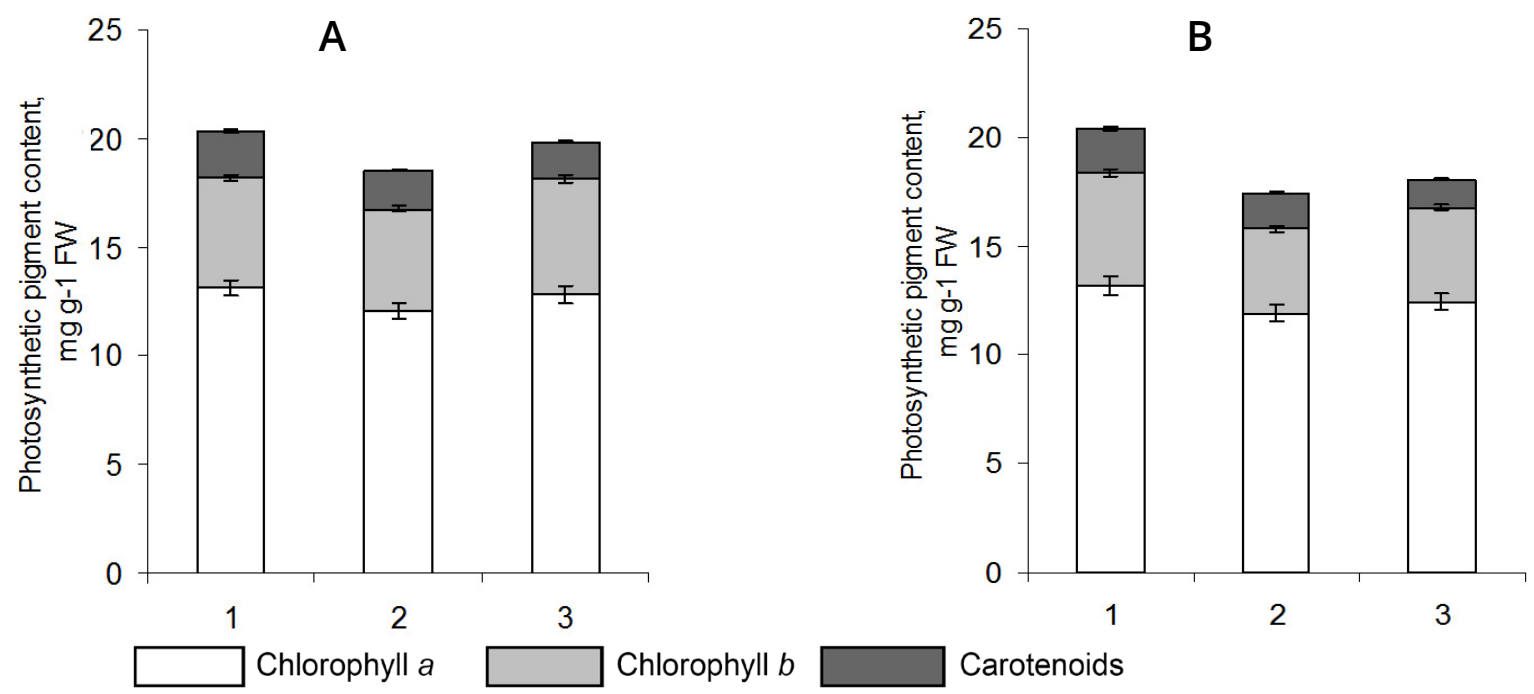

Figure 5. The effects of EMFs of Wi-Fi router and gadget M4 on the content of photosynthetic pigments in the leaves of juvenile wheat plants (weighted averages): $\mathbf{A}$ - without remote $\mathrm{Wi}-\mathrm{Fi}, \mathbf{B}$ - remote Wi-Fi present. 1 - without Wi-Fi router, 2 - Wi-Fi router, 3 - Wi-Fi router + gadget M4. Vertical bars - LSD.

Halgamuge et al., 2015). The $24 \mathrm{~h}$ exposure to cell phone electromagnetic field radiation (EMR) with the frequency of $1805-1850 \mathrm{MHz}$ and mean power density of $0.4809 \mathrm{~mW} / \mathrm{cm}^{2}$ significantly reduced the height and fresh weight of mung beans, hyacinth bean and mologa bean seedlings (Chen \& Chen, 2014). Some authors explain these growth reductions by decreased photosynthetic potential (Răcuciu et al., 2015). In particular, it was found that exposure of maize (Zea mays L.) seeds to $1 \mathrm{GHz}$ electromagnetic field inside a transverse electromagnetic cell for 1-8 hours led to inhibition of photo-assimilatory pigments level in 12-day seedlings grown from exposed seeds (Răcuciu et al., 2015). Kumar et al. (2015) showed a $13 \%$ decrease in total chlorophyll content after $4 \mathrm{~h}$ exposure of maize seedlings to $1800 \mathrm{MHz}\left(332 \mathrm{~mW} \cdot \mathrm{m}^{-2}\right)$. These modifications may be related to abnormal photosynthetic activity, which relies on many parameters, including chlorophylls' and carotenoids' content.

Photosynthesis is the primary metabolic process that provides the formation of plant biomass. The performance of photosynthesis depends on the content of photosynthetic pigments, their composition, and the ratio 
(Kumar et al., 2015). In our studies, the content of chlorophyll $a$ was the most tolerant to EMF of the Wi-Fi router and decreased by $9 \%$ only. In comparison, the content of chlorophyll $b$ and carotenoids decreased by 17 and $18 \%$, respectively (Fig. 5).

In the presence of gadget M4 the content of chlorophylls $a$ and $b$ increased as compared to the treatment with Wi-Fi router only. Meanwhile, the content of carotenoids did not significantly change when exposed to the EMF of the M4 gadget. The observed stimulation of the chlorophylls' $a$ and $b$ content testified to the adaptation of biosynthetic pathways in the direction of increasing their resistance to EMF by the tested gadget M4.

Carotenoids and chlorophyll $b$ are pigments that play a significant role in the protection of photosynthetic systems against photooxidative processes. They are efficient antioxidants scavenging singlet molecular oxygen and peroxyl radicals (McElroy \& Kopsell, 2009). Therefore, the content of chlorophyll $b$ and carotenoids is sensitive to the influence of abiotic and biotic stress factors, and the ratio of these pigments to the content of chlorophyll $a$ is a marker of the plant stress.

The inhibiting effect of EMFs on plants is often explained with the damage of protective antioxidant systems (Tkalec et al., 2005; 2007; Vian et al., 2016). In particular, Tkalec et al. (2007) showed that exposure for $2 \mathrm{~h}$ to EMFs of 400 and $900 \mathrm{MHz}$ induced oxidative stress as well as unspecific stress responses (enhanced lipid peroxidation and $\mathrm{H}_{2} \mathrm{O}_{2}$ content accompanied by diminished antioxidative enzymes activity) in Lemna minor. The observed effects markedly depended on the field frequencies applied as well as on other exposure parameters like strength, modulation, and exposure time (Tkalec et al., 2007).

In our study, photosynthetic pigment content inhibition caused by EMF of the Wi-Fi router was related to the reduction of chloroplastogenesis. EMR of the Wi-Fi router reduced $21-25 \%$ of the number of chloroplasts in the mesophyll cells of leaf tissues in wheat juvenile plants (Table 1; Fig. 6).

The negative impact of the EMR of the Wi-Fi router is mainly due to its nonspecific destructive effect on the cell membrane structure, including influence on the chloroplasts. The use of the gadget M4 partially
Table 1. The effects of EMFs of Wi-Fi router and gadget M4 on the mean number of chloroplasts per a mesophyll cell in foliar tissues of juvenile wheat plants. F - Fisher's criterion, P - significance level.

\begin{tabular}{lll}
\hline Assessment & $\begin{array}{l}\text { With remote } \\
\text { Wi-Fi }\end{array}$ & $\begin{array}{l}\text { Without } \\
\text { remote Wi-Fi }\end{array}$ \\
\hline Without Wi-Fi & 45 & 48 \\
Wi-Fi & 34 & 38 \\
Wi-Fi+gadget M4 & 41 & 43 \\
F & 3.9 & 3.7 \\
P & 0.0 & 0.0 \\
LSD & 0.7 & 0.9 \\
\hline
\end{tabular}

compensated the inhibiting effect of EMF of the Wi-Fi router on the genesis of chloroplasts in mesophyll cells of juvenile wheat plants. The results of this study confirmed the opinion of other authors (Tkalec et al., 2005; 2007; Vian et al., 2016) that the suppressive effect of EMF of Wi-Fi systems on the growth and development of higher plants may be related to their inhibition of the activity of antioxidant systems and photosynthetic activity, including synthesis of photosynthetic pigment and genesis of chloroplasts. The use of the experimental gadget M4 protects these physiological processes, which leads to the restoration of healthy growth and development of plants.

The attenuation effect of gadget M4 against the damaging effect of EMFs of anthropogenic origin is promising, and further investigations are required to observe the effects in the long term, from sowing to maturity, including the next generation of plants.

\section{Conclusions}

As a result of our studies, the sensitivity of physiological processes of growth and development, photosynthetic activity of wheat seedling to EMF of the Wi-Fi router, and experimental gadget M4 were determined. The root length index was found to be the most sensitive to the EMF of the tested devices. Significant destructive effect of the EMF of the Wi-Fi router on photosynthetic pigment complex (especially on the content of chlorophyll $b$ and carotenoids) and chloroplastogenesis have been described. 

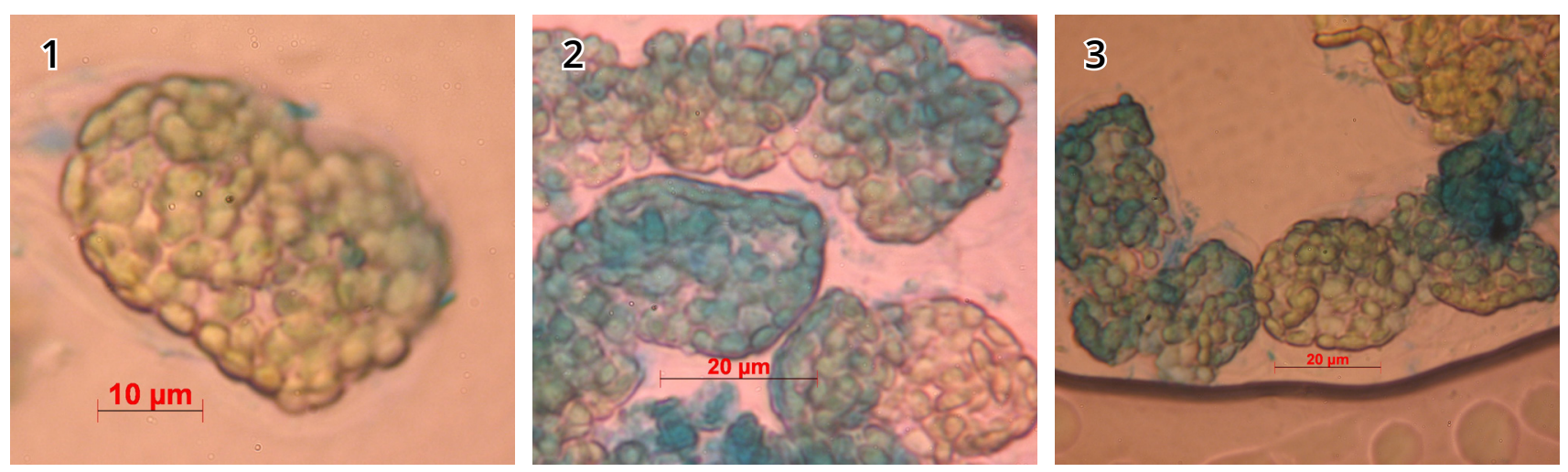

Figure 6. The number of chloroplasts per a mesophyll cell in the leaves of juvenile wheat plants: 1 - without Wi-Fi router, 2 - Wi-Fi router, 3 - Wi-Fi router + gadget M4.

The application of the experimental gadget M4 protected the mentioned above physiological processes, which led to the restoration of healthy growth and development of wheat at seedling and juvenile phase. Further investigation of the protective effect of the experimental gadget M4 against the damaging effect of EMF is promising.

The results of our studies confirmed the good potential of indices of wheat seed germination and growth of roots of seedlings and juvenile plants for the phytoindication of EMF influence.

\section{References}

Afzal, M., \& Mansoor, S. (2012). Effect of mobile phone radiations on morphological and biochemical parameters of mung bean (Vigna radiata) and wheat (Triticum aestivum) seedlings. Asian Journal of Agricultural Sciences, 4(2), 149-152.

Akbal, A., Kiran, Y., Sahin, A., Turgut-Balik, D., \& Balik, H. H. (2012). Effects of electromagnetic waves emitted by mobile phones on germination, root growth, and root tip cell mitotic division of Lens Culinaris Medik. Polish Journal of Environmental Studies, 21(1), 23-29.

Atasoy, H. I., Gunal, M. Y., Atasoy, P., Elgun, S., \& Bugdayci, G. (2013). Immunohistopathologic demonstration of deleterious effects on growing rat testes of radiofrequency waves emitted from conventional Wi-Fi devices. Journal of Pediatric Urolology, 9(2), 223-229. https://doi. org/10.1016/j.jpurol.2012.02.015

Blinova, N. K, Starovoytova, O. D., Ishkova, Y. G., \& Tarasov, V. Y. (2015). Effect of electromagnetic radiation on Wi-Fi vigor seeds. Bulletin of the East Ukrainian National University named after Vladimir Dahl, 224(7), 7-11.
Castellina, A., \& Donato, F. (2012). Astrophysics of galactic charged cosmic rays. In T. D. Oswalt, I. S. McLean, H. E. Bond, L. French, P. Kalas, M. Barstow, G. F. Gilmore, W. Keel (Eds.), Planets, stars, and stellar systems (pp. 725-788). Dordrecht: Springer.

Chen, H.-Y., \& Chen, C. (2014). Effects of mobile phone radiation on germination and early growth of different bean species. Polish Journal of Environmental Studies, 23(6), 1949-1958. https:// doi.org/10.15244/pjoes/24254

Halgamuge, M. N., Yak, S. K., \& Eberhardt, J. L. (2015). Reduced growth of soybean seedlings after exposure to weak microwave radiation from GSM 900 mobile phone and base station. Bioelectromagnetics, 36(2), 87-95. https://doi. org/10.1002/BEM.21890

Hiscox, J. D., \& Israelstam, C. F. (1979). A method for the extraction of chlorophyll from leaf tissue without maceration. Canadian Journal of Botany, 57, 1332-1334.

Jinapang, P., Prakob, P., Wongwattananard, P., Islam, N. E., \& Kirawanich, P. (2010). Growth characteristics of mung beans and water convolvuluses exposed to $425-\mathrm{MHz}$ electromagnetic fields. Bioelectromagnetics, 31(7), 519-527. https://doi.org/10.1002/ bem.20584

Kostoff, R. N, Heroux, P., Aschner, M., \& Tsatsakis, A. (2020). Adverse health effects of $5 \mathrm{G}$ mobile networking technology under real-life conditions. Toxicology Letters, 323(1), 35-40. https://doi.org/10.1016/j. toxlet.2020.01.020

Kumar, A., Kaur, S., Chandel, S., Pal Singh H., Batish, D. R., \& Kohli R. K. (2020). Comparative cyto- and genotoxicity of $900 \mathrm{MHz}$ and $1800 \mathrm{MHz}$ electromagnetic field radiations in root meristems of Allium cepa. Ecotoxicology and Environmental Safety, 188(30), 109786. https://doi. org/10.1016/j.ecoenv.2019.109786 
Kumar, A., Singh, H. P., Batish, D. R., Kaur, S., \& Kohli, R. K. (2015). EMF radiations (1800 MHz)inhibited early seedling growth of maize (Zea mays) involves alterations in starch and sucrose metabolism. Protoplasma, 253(4), 1-7. https:// doi.org/10.1007/s00709-015-0863-9

McElroy, J. S., \& Kopsell, D. A. (2009). Physiological role of carotenoids and other antioxidants in plants and application to turfgrass stress management. New Zealand Journal of Crop and Horticultural Science, 37(4), 327-333. https://doi. org/10.1080/01140671.2009.9687587

Mildažienè, V., Aleknavičiūtè, V., Žūkienè, R., Paužaitè, G., Naučienè, Z., Filatova, I., Lyushkevich, V., Haimi, P., Tamošiūnè, I., \& Baniulis, D. (2019). Treatment of common sunflower (Helianthus annus L.) seeds with radio-frequency electromagnetic field and cold plasma induces changes in seed phytohormone balance, seedling development and leaf protein expression. Scientific Reports, 9(1), 6437. https:// doi.org/10.1038/s41598-019-42893-5

Mokronosov, A. T. (1978). Method for quantitative assessment of the structure and functional activity of photosynthetic tissues and organs. In A. T. Mokronosov, \& N. A. Borzenkova (Eds.), Works on applied botany, genetics and selection (pp. 119-131). Sverdlovsk: Uralski Gosuniversitet. (In Russian)

Moroz, I., \& Chemerys, I. (2017). Influence of electromagnetic radiation on plant growth. In Proceedings of the conference for junior researchers "Science - Future of Lithuania" (pp. 1-8). Vilnius, Lithuania. https://doi.org/10.3846/aainz.2017.012

Panagopoulos, D.J. (2019). Comparing DNA damage induced by mobile telephony and other types of man-made electromagnetic fields. Mutation Research / Reviews in Mutation Research, 781, 5362. https://doi.org/10.1016/j.mrrev.2019.03.003

Răcuciu, M., Iftode, C., \& Miclaus, S. (2015). Inhibitory effects of low thermal radiofrequency radiation on physiological parameters of Zea mays seedlings growth. Romanian Journal of Physics, 60(3-4), 603-612.
Sharma, S., \& Parihar, L. (2014). Effect of mobile phone radiation on nodule formation in the leguminous plants. Current World Environment Journal, 9(1), 145-155. https://doi.org/10.12944/ CWE.9.1.21

Singh, H. P., Sharma, V. P., Batish, D. R., \& Kohli, R. K. (2012). Cell phone electromagnetic field radiations affect rhizogenesis through impairment of biochemical processes. Environmental Monitoring and assessment, 184(4), 1813-1821. https://doi.org/10.1007/s10661011-2080-0

Tkalec, M., Malarić, K., \& Pevalek-Kozlina, B. (2005). Influence of 400, 900, and $1900 \mathrm{MHz}$ electromagnetic fields on Lemna minor growth and peroxidase activity. Bioelectromagnetics, 26(3), 185-193. https://doi.org/10.1002/bem.20104

Tkalec, M., Malarić, K., \& Pevalek-Kozlina, B. (2007). Exposure to radiofrequency radiation induces oxidative stress in duckweed Lemna minor $\mathrm{L}$. Science of the Total Environment, 388(1-3), 78-89. https://doi.org/10.1016/j.scitotenv.2007.07.052

Vasilieva, E. G. (2008). The mechanism of influence of electromagnetic fields on living organism. Bulletin of the Astrakhan State Technical University, 44(3), 186-191.

Vian, A., Davies, E., Gendraud, M., \& Bonnet, P. (2016). Plant responses to high frequency electromagnetic fields. BioMed Research International, 2016, 1830262. https://doi. org/10.1155/2016/1830262

Waldmann-Selsam, C., Balmori-de la Puente, A., Breunig, H., \& Balmori, A. (2016). Radiofrequency radiation injures trees around mobile phone base stations. Science of The Total Environment, 572, 554-569. https://doi.org/10.1016/j. scitotenv.2016.08.045

Zadoya, N. I. (2014). Electromagnetic safety: A textbook for bachelors in the field of power engineering and electrical engineering. Rubtsovsk: Rubtsovsk Industrial Institute. (In Russian)

\title{
Вплив електромагнітного поля Wi-Fi систем та експериментального приладу M4 на процеси росту, розвитку та фотосинтез пшениці
}

\author{
Ж. Рош ${ }^{1}$, Н.П. Дідик ${ }^{2 *}$, Б.О. Іваницька ${ }^{2}$, Н.В. Заіменко ${ }^{2}$, О.О. Чудовська ${ }^{2}$
}

\footnotetext{
1 SAS "IRDT", вул. Сімона Перрота, 8, Денонвіль, 28700, Франція

2 Національний ботанічний сад імені М.М. Гришка Національної академії наук України, вул. Тімірязєвська, 1, Київ, 01014, Україна; * nataliya_didyk@ukr.net
} 
Мета - оцінити вплив електромагнітного поля Wi-Fi систем та експериментального приладу M4 (розробленого компанією SAS "IRDT", Франція) на проростання насіння, ріст та фотосинтетичну активність ювенільних рослин пшениці.

Матеріал та методи. Рослини вирощували за контрольованих умов освітлення, температури та вологості протягом восьми діб у вегетаційному досліді, який моделював наступні умови: (1) відсутність електромагнітного поля Wi-Fi систем (контроль); (2) на відстані 30 см від працюючого Wi-Fi роутера; (3) на відстані 30 см від працюючих Wi-Fi роутера та приладу M4.

Розвиток тест-рослин та їхній життєвий стан оцінювали за схожістю насіння, показниками росту (висота надземноїчастини, довжина коренів, кількістю бічних коренів, маса сухої речовини надземної та підземної частин), вмістом фотосинтетичних пігментів у листках та кількістю хлоропластів на клітину мезофілу у тканинах листків.

Результати. Встановлено, що електромагнітне поле Wi-Fi роутера спочатку прискорювало, але потім пригнічувало проростання насіння, знижувало приріст надземних частин та коренів, вміст фотосинтетичних пігментів та кількість хлоропластів у клітинах мезофілу листків ювенільних рослин пшениці.

Довжина кореня була найчутливішим морфометричним показником до впливу електромагнітного поля Wi-Fi роутера. Застосування приладу M4 повністю компенсувало негативний вплив Wi-Fi роутера на схожість насіння, приріст надземної частини та частково компенсувало пригнічення приросту коренів, хлоропластогенезу, а також вмісту хлорофілів $a$ та $b$ у листках пшениці.

Висновки. Захисна дія приладу M4 щодо електромагнітних полів антропогенного походження $\epsilon$ перспективною для подальших досліджень наслідків більш тривалого впливу - від посіву до дозрівання, включаючи наступні покоління тест-рослин.

Ключові слова: Triticum aestivum, радіочастотні електромагнітні поля, Wi-Fi роутер, пристрій M4, ріст рослин, розвиток рослин, фотосинтетичні пігменти, хлоропластогенез 